\title{
Апробация ДНК-маркеров генов устойчивости к раку картофеля и золотистой картофельной нематоде при оценке сортов и гибридов картофеля
}

\author{
И.В. Тоцкий ${ }^{1 *}$, А.Д. Сафонова ${ }^{1}$, Е.К. Хлесткина ${ }^{1,2}$, А.В. Кочетов ${ }^{1}$ \\ ${ }^{1}$ ФИЦ Институт ичтоологии и генетики СО РАН, Новосибирск, Россия \\ ${ }^{2}$ ФИЦ Всероссийский институт генетических ресурсов растений имени Н.И. Вавилова (ВИР), \\ Санкт-Петербург, Россия \\ *e-mail:totsky@bionet.nsc.ru
}

Обнаружение ДНК-маркеров, сцепленных с хозяйственно ценными генами, значительно облегчает и ускоряет отбор селекционных форм с заданными комбинациями аллелей и фенотипическими признаками, так как является намного менее трудоемким и дорогостоящим методом, особенно в сравнении с фенотипированием в лабораторных или полевых условиях, например, фитопатологическим тестированием.

Целью исследования является апробация применимости известных ДНК-маркеров для диагностики генов устойчивости к различным заболеваниям у сортов и гибридных форм отечественной селекции. Материалом исследований послужили сорта Solanum tuberosum L. из коллекции ГенАгро ИЦиГ CO РАН и селекционные гибриды СибНИИРС - филиала ИЦиГ СО РАН.

На основе анализа литературных данных был выбран ряд диагностических маркеров для выявления генов устойчивости к различным заболеваниям: маркера CP113 (Niewohner et al., 1995) к гену H1, отвечающему за устойчивость к золотистой картофельной нематоде (ЗКН, Globodera rostochiensis, патотип 1); маркер NL25 к гену Sen1, сцепленному с устойчивостью к раку картофеля (возбудитель Synchytrium endobioticum) (Hehl et al., 1999; Bormann et al., 2004; Gebhardt et al., 2006).

Геномная ДНК 32 сортов картофеля анализировалась при помощи маркеров NL25 и СР113. Источник сведений об устойчивости сортов - www.gossort.com. Оценка устойчивости селекционных гибридов проводилась на базе ВНИИКХ (к раку) и ВИЗР (ЗКН). Аллель гена Sen 1, определяющий устойчивость к раку, диагностирован у 21 образца (65,6 \%) с помощью маркера NL25. Между наличием маркера NL25 и устойчивостью к раку картофеля выявлена достоверная связь $\left(r^{s}=0,531, p<0,05\right.$ $\left.\left(r_{\text {крит }}^{\text {s }}=0,35\right)\right)$. По результатам генотипирования с использованием маркера CP113 у 16 из 30 образцов (53,3 \%) был диагностирован ген $H 1$, определяющий устойчивость к ЗКН. Однако достоверной связи между наличием маркера СР113 и устойчивостью образцов картофеля у ЗКН не обнаружено $\left(r^{s}=0,164, p>0,05\right.$ $\left.\left(r_{\text {крит }}^{s}=0,362\right)\right)$. На основе полученных данных для дальнейшего применения в селекционных программах СибНИИРС - филиала ИЦиГ СО РАН рекомендован один из двух протестированных маркеров - NL25. Его использование позволит на ранних этапах селекции исключать гибриды, не устойчивые к раку картофеля. Благодарности: Работа подготовлена при поддержке Российского научного фонда, грант № 16-16-04073. 